\title{
Arsenic-Induced Neurotoxic \& Carcinogenic Effects on Humans
}

\author{
Mahipal Singh Sankhla* and Rajeev Kumar \\ Galgotias University, India
}

Submission: July 31, 2018; Published: August 24, 2018

*Corresponding author: Mahipal Singh Sankhla, Research Scholar, Division of Forensic Science, SBAS, Galgotias University, Greater Noida, India, Email: mahipal4n6@gmail.com

\begin{abstract}
Human exposure to arsenic is a worldwide major health problem. Chronic exposure of arsenic which cause neurological toxicity \& carcinogenic Toxicity, arsenic is considered as most neurotoxic \& carcinogenic agent which affect humans. Arsenic produce toxicity in neurobehavioral or reducing oxidative anxiety and dopaminergic functions in human. Arsenic effected immune system destruction, neurotoxicity, and communication with enzymes and nervous system. Exposure of arsenic through early fetal growth can origin brain injury at doses taken lower amount than individuals effect adult brain function. Arsenic are known as a major heavy metal causing carcinogen in human. Arsenic contaminated water \& food are developed carcinogen and involved modes of action contain epigenetic effects, mainly via DNA and developed cancer tumor in the body.

Keywords: Arsenic; Neurotoxicity; Carcinogenic; Toxicity; HumanAbstract
\end{abstract}

\section{Introduction}

Toxicology waste pollutions of industrial nations by major heavy metals and the metalloid arsenic is largely the significance of past emissions by nonferrous industries. Although severe procedures and controls have been put into place through the last years, high levels of these contaminants still persevere in the soils and sediments and consequently also in the food chain with likely significances of chronic environmental exposure of the populations living in those regions. Additionally, natural pollution such as geologic arsenic or routine connected aspects such as the inorganic mercury in dental combination can additional contribute to increase the load of human exposure to these toxicants [1]. Arsenic, a heavy metal is commonly dispersed in the environment due to its natural and anthropogenic sources [2-4]. High levels of inorganic arsenic are originating in ground water in several counties of the world because of geochemical procedures affectation major chronic health risks to people [5-8]. Learning and memory development include a complex mechanism that surrounds the archive and the recovery of experiences, existence consequently related with knowledge, which is well-defined as the capability to alter performance through experiences that have been kept in memory [9]. Three types of memories are generally acknowledged: working, small, and long-term memory. One-trial inhibitory avoidance (IA) is generally working as a conditioned fear example, known since Pavlov. In reflexive avoidance preparing, animals learn to secondary the conditioned stimulus (CS) with unconditioned stimulus (US), and through CS-US association formation, the conditioned stimulus (CS) generates various conditioned responses (CRs) that share similar characteristics with innate fear response [10,11]. An important aspect of appropriately assigning the potential degree of hazard posed by a given level of exposure to any carcinogen is a knowledge of carcinogenic mechanisms, which helps to define appropriate models for risk assessment, particularly at lower levels of exposure. Generation of tumors in animals can be an invaluable aid in defining carcinogenic mechanisms. In this regard, while exposure to inorganic arsenic in humans is clearly carcinogenic $[12,13]$, carcinogenesis in animals resulting from exposure to inorganic arsenic, when given as a single agent, has been difficult to demonstrate convincingly $[13,14]$. Indeed, it is thought that the definition of the mechanism or mechanisms of arsenic carcinogenicity has been impeded by a lack of clear rodent models [15]. Heavy Metals are recognized as causes of developmental neurotoxicity. The major impact of heavy metals is on the peoples who were directly in exposure of industries. Nowadays the major reason of neurotoxicity by which human affected is due to toxicity from mixture of heavy metal instead of single metals. The effect of human exposure to mixtures of heavy metals is presently a major research area in neurotoxicology [16].

\section{Neurotoxicity of arsenic (As)}

Ingestion of arsenic polluted drinking water has long been recognized to cause central neuropathy in adults [17]. 
Developing neurotoxicity due to arsenic was reported in 1955 in Japan, where ingesting of powdered milk polluted with arsenic led to over 12000 cases of poisoning and 131 deaths. A followup study of three groups of adolescents born during the time of the milk contamination included one group that was fully breast-fed, one that was exposed to the tainted milk product, and one that received other supplements, but no contaminated formulation Associated with national rates, a ten-fold growth in mentally-retarded persons was seen in the contaminated milk collection poor school chronicles, emotional in the exposed group. Since these findings were initially reported in Japanese journals not easily available elsewhere $[18,19]$, they have often been overlooked, even in the most thorough risk assessments of arsenic exposure $[13,20]$. Arsenic is present in ground water worldwide, and industrial pollution is widespread. Studies of school-age teenagers presented cognitive shortages related with drinking water pollution [19] and raised urinary arsenic concentrations [20,21]. Comparable results were found in children with arsenic coverage from a smelter [22]. Likely joint adversarial effects on IQ produced by arsenic and manganese coverages was recommended by metal absorptions in hair in children existing near a harmful waste site [23]. While evidence for subclinical neurodevelopmental neurotoxicity of arsenic is less well established than for lead and methylmercury, the data are reliable and fit with the high-exposure results from Japan. Still, regulatory action does not highlight the need to guard the evolving brain against this neurotoxic element $[20,24]$.

\section{Carcinogenicity of arsenic (As)}

Arsenic produces tumors in investigational animals, epidemiological studies show, indeed, that the incidence of epidermoid carcinomas of the skin and lungs, and of precancerous dermal keratoses, is significantly increased in human subjects who have been chronically exposed to arsenic compounds by oral or respiratory routes. Implication of arsenic in some skin cancers was already suspected 100 years ago and, in 1947 [24]. Provided an extensive review of arsenical cancers with case reports dating back to 1891. It is noteworthy that arsenic-induced neoplasms of skin and internal organs may look after numerous periods of latency $[25,26]$. Increased incidences of respiratory cancers have been observed after occupational exposure in the smelting industry [27-31] and in the chemical industry $[32,33]$. Evaluated the mortality rate of workers engaged in the production of arsenical pesticides and found an excess of death due to lung cancer (about twofold) [34]. Who studied the proportional mortality in about 2000 deaths among workers occupied in the production of lead arsenate and calcium arsenate [35]. Carcinogenesis is a multiple procedure connecting the unsuitable inspiration of normal cellular genes to develop oncogenes, and the inactivation of other cellular genetic factor called tumor suppressor genes. The prototypic tumor suppressor genes are well suited as a molecular link between the causes of cancer, i.e., carcinogenic chemical and physical agents and certain viruses, and the development of clinical cancer. The crucial differences between normal and cancer cells stem from discrete changes in specific genes controlling proliferation and tissue homeostasis [36]. Progress in the fields of molecular carcinogenesis and molecular epidemiology increases our ability to assess cancer risk. Because regulatory decisions based on cancer risk assessments have significant public health and economic consequences, the scientific basis of risk assessment continues to be, and should continue to be, actively investigated [37]. Long-term exposure to arsenic affects the gastrointestinal tract, circulatory system, skin, liver, lung, kidneys, nervous system, and heart. Evidence from epidemiological studies clearly shows that exposure to inorganic arsenic increases the risk of cancer. In workers exposed by inhalation, the predominant carcinogenic effect is an increased risk of lung cancer $[38,39]$, when exposure occurs orally, the main carcinogenic effect is increased risk of skin cancer. In addition to skin cancer, increased risk of several internal cancers (mainly of liver, kidney, lung, colon, and bladder) have been reported with arsenic exposure.

\section{Discussion}

These Review paper studies show that arsenic is causing carcinogenicity \& neurotoxicity. The arsenic exposure in childhood can result in cognitive and behavioral deficits in children. Neurotoxicologically disorders such as autism, attention deficit disorder, mental retardation, and cerebral palsy are common but dangerous as it can cause lifelong disability. Metals are universal and take dangerous part in neurobiology. Heavy metals generate toxic effects on different organs of body and by this differently affect Humans. Heavy metals contaminate in water, air, soil etc. and affect human beings by different ways. Arsenic chronic exposure is carcinogens effect on human body. Exposure to arsenic happens occupationally in many industries, containing mining, pesticide, E-waste, Swage as well as environmentally from both industrialized and natural sources. Inhalation is the main path of arsenic exposure in professional settings, while consumption of polluted drinking water is the major source of significant environmental exposure worldwide. Drinking water pollution by arsenic residues a main human health problem. Acute and chronic arsenic contamination of drinking water has been described in many countries of the world, where a large amount of drinking water is polluted with high amount of concentrations of arsenic or produce cancer cell in human.

\section{Conclusion}

Arsenic are recognized as causes of developmental toxicity in humans. The major impact of Arsenic is on the peoples who were directly in exposure of industries. Nowadays the major reason of neurotoxicity \& carcinogenicity by which human affected is due to toxicity from mixture of heavy metal instead of arsenic. The effect of human exposure to mixtures of heavy metals is presently a major research area in neurotoxicology. This proposes that contact to arsenic may result in higher order of neurological \& carcinogenicity effects than to single metals and this enhance 
need to understand the toxicology of complex mixtures. Analysis of concentration of arsenic in chemicals before allowing them to be marketed is concerned to prevent toxicity but has been seen active only in recent years. These consisted of employees who were exposed to high doses of elements either by inhalation or accidental ingestion and began to develop permanent neurologic damage and cancer cell. Some of this information originated in industries where arsenic exposure was common a major health risk.

\section{References}

1. De Burbure C, Buchet JP, Leroyer A, Nisse C, Haguenoer JM, et al. (2006) Renal and neurologic effects of cadmium, lead, mercury, and arsenic in children: evidence of early effects and multiple interactions at environmental exposure levels. Environmental health perspectives 114(4): 584-590.

2. Rodriguez VM, Dufour L, Carrizales L, Diaz-Barriga F, JimenezCapdeville ME (1998) Effects of oral exposure to mining waste on in vivo dopamine release from rat striatum. Environ Health Perspect 106(8): 487-491.

3. Banu GS, Kumar G, Murugesan AG (2009) Effects of leaves extract of Ocimum sanctum $L$. on arsenic-induced toxicity in Wistar Albino rats. Food Chem Toxicol 47: 490-495.

4. Das AK, Bag S, Sahu R, Dua TK, Sinha MK, et al. (2010) Protective effect of Corchorus olitorius leaves on sodium arsenite-induced toxicity in experimental rats. Food Chem Toxicol 48(1): 326-335.

5. National Research Council (2001) Arsenic in drinking water. National Academy Press, Washington, DC, USA.

6. Khan MMH, Hossain MK, Kobayashi K, Sakauchi F, Yamashita T, et al. (2005) Levels of blood and urine chemicals associated with longer duration of having arsenicosis in Bangladesh. Int J Environ Health Res 15: 289-301.

7. Mukherjee A, Sengupta MK, Hossain MA, Ahamed S, Das B, et al. (2006) Arsenic contamination in groundwater: a global perspective with emphasis on the Asian scenario. J Health Popul Nutr 24(2): 42-163.

8. Brinkel J, Khan MMH, Kraemer A (2009) A systematic review of arsenic exposure and its social and mental health effects with special reference to Bangladesh. Int J Environ Res Public Health 6: 1609-1619.

9. Clark CR, Alexander GFE, McFarlane C, Morris P, Weber D, et al. (2000) Updating working memory for words: a PET activation study. Hum Brain Mapp 9(1): 42-54.

10. Rescorla RA (1968) Probability of shock in the presence and absence of CS in fear conditioning. J Comp Physiol Psychol 66(1): 1-5.

11. Kim JJ, Jung MW (2006) Neural circuits and mechanisms involved in Pavlovian fear conditioning: a critical review. Neurosci Biobehav Rev 30(2): 188-202.

12. IARC (1987) International agency for research on cancer monographs on the evaluation of carcinogenic risks to humans: supplement 7 , overall evaluations of carcinogenicity: an updating of IARC monographs
Volumes 1 to 42, IARC Scientific Publications Lyon, France, pp. 100106.

13. NRC (1999) Arsenic in the Drinking Water. National Academy Press, Washington, DC, USA, pp. 1-310.

14. Kitchin KT (2001) Recent advances in arsenic carcinogenesis: modes of action, animal model systems, and methylated arsenic metabolites. Toxicol Appl Pharmacol 172(3): 249-261.

15. Simeonova PP, Luster MI (2000) Mechanisms of arsenic carcinogencity: genetic or epigenetic mechanisms? J Environ Pathol Oncol 19(3): 281286.

16. Sankhla MS, Sharma K, Kumar R Heavy Metal Causing Neurotoxicity in Human Health.

17. Landrigan PJ (1981) Arsenic-state of the art. Am J Ind Med 2(1): 5-14.

18. Yamashita N, Doi M, Nishio M, Hojo H, Tanaka M (1972) Recent observations of Kyoto children poisoned by arsenic tainted 'Morinaga dry milk' [in Japanese]. Nippon Eiseigaku Zasshi 27(4): 364-99.

19. Ohira M, Aoyama H (1973) Epidemiological studies on the Morinaga Powdered Milk Poisoning Incident [in Japanese]. Nippon Eiseigaku Zasshi 27(6): 500-531.

20. Tsai SY, Chou HY, The HW, Chen CM, Chen CJ (2003) The effects of chronic arsenic exposure from drinking water on the neurobehavioral development in adolescence. Neurotoxicology 24(4-5): 747-753.

21. Wasserman GA, Liu X, Parvez F, Ahsan H, Factor-Litvak P, et al. (2004) Water arsenic exposure and children's intellectual function in Araihazar, Bangladesh. Environ Health Perspect 112(13): 1329-1333.

22. Calderon J, Navarro ME, Jimenez-Capdeville ME, Santos-Diaz MA, Golden A, et al. (2001) Exposure to arsenic and lead and neuropsychological development in Mexican children. Environ Res 85(2): 69-76.

23. Wright RO, Amarasiriwardena C, Woolf AD, Jim R, Bellinger DC (2006) Neuropsychological correlates of hair arsenic, manganese, and cadmium levels in school-age children residing near a hazardous waste site. Neurotoxicology 27(2): 210-216.

24. International Programme on Chemical Safety (2001) Arsenic and arsenic compounds, $\left(2^{\text {nd }} \mathrm{edn}\right)$, Environmental Health Criteria 224, World Health Organization Geneva, Switzerland.

25. Neubauer O (1946) Arsenical cancer; a review. Br J Cancer I 1(2): 192196.

26. Denk RH, Holzmann HJL, Greve D Uber Arsensp//tsch /den bei obduzierten Moselwinzern, Med Welt 20: 557-567.

27. Arguello RA, Cenget DD, EE (1969) Tel/o, Cancer y arsenicismo regional endemico en Cordoba. Rev Argent DermatosiffloL 22: 461-487.

28. Bradford Hill A, Farting EL (1948) Studies on the incidence of cancer in a factory handling inorganic compounds of arsenic, I. Mortality experience in the factory, Br J Ind Med 5(1): 1-6.

29. Kuratsune M, Tokudome S, Shirakusa T, Yoshida M, Tokumitsu Y (1975) Occupational lung cancer among copper smelters. Int J Cancer 13(4): $552-558$. 
30. Lee AM, Fraumeni JF (1969) Arsenic and respiratory in man: An occupational study. J Natl Cancer Inst 42: 1045-1052.

31. Mflham S, Strong T (1974) Human arsenic exposure in relation to a copper smelter. Environ Res 7: 176-182.

32. Oswald H, Goerttler K (1971) Arsenic-induced leucosis in mice after dlaplacental and postnatal application. Verh Deut Ges Pathol 55: 289293.

33. Ott MG, Holder BB, Gordon HL (1974) Respiratory cancer and occupational exposure to arsenicals. Arch Environ Health 29(5): 250255.

34. Osburn HS (1969) Lung cancer in a mining district in Rhodesia. S Afr Med J 43(43): 1307-1312.

35. Harris CC (1996) p53 tumor suppressor gene: at the crossroads of molecular carcinogenesis, molecular epidemiology, and cancer risk assessment. Environ Health Perspect 104(suppl 3): 435-439.
36. Mazumder DN, Haque R, Ghosh N, De BK, Santra A, et al. (1998) Arsenic levels in drinking water and the prevalence of skin lesions in West Bengal, India. Int J Epidemiol 27(5): 871-877.

37. Enterline PE, Henderson VL, Marsh GM (1987) Exposure to arsenic and respiratory cancer: a reanalysis. Am J Epidemiol 125(6): 929-938.

38. Lee-Feldstein A (1986) Cumulative exposure to arsenic and its relationship to respiratory cancer among copper smelter employee. J Occup Med 28(4): 296-302.

39. Tchounwou PB, Wilson B, Ishaque A (1999) Important considerations in the development of public health advisories for arsenic and arsenic containing Compounds in drinking water. Rev Environ Health 14(4): 211-229.

\section{Your next submission with Juniper Publishers will reach you the below assets}

- Quality Editorial service

- Swift Peer Review

- Reprints availability

- E-prints Service

- Manuscript Podcast for convenient understanding

- Global attainment for your research

- Manuscript accessibility in different formats

( Pdf, E-pub, Full Text, Audio)

- Unceasing customer service

Track the below URL for one-step submission https://juniperpublishers.com/online-submission.php 